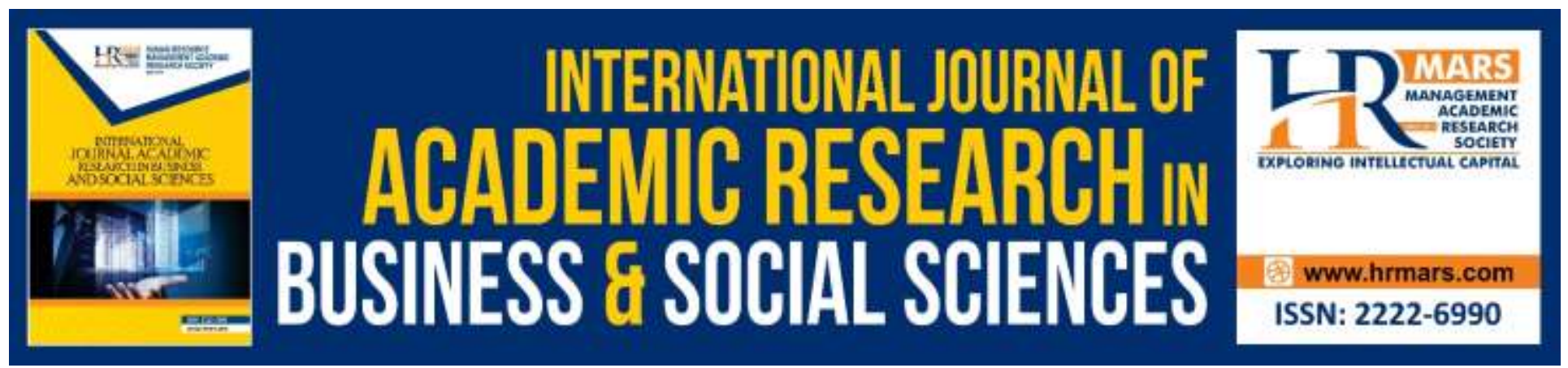

\title{
Expert User Education: Redefining Role of Design and Designers of IR 4.0 in Rehabilitation Setting
}

\author{
Nurhikma Binti Mat Yusof, YM Raja Azmeer Bin YM Raja Effendi, Saiful \\ Hasley Bin Ramli
}

To Link this Article: http://dx.doi.org/10.6007/IJARBSS/v9-i13/6863

DOI: $10.6007 /$ IJARBSS/v9-i13/6863

Received: 22 May 2019, Revised: 19 June 2019, Accepted: 02 July 2019

Published Online: 23 August 2019

In-Text Citation: (Yusof et al., 2019)

To Cite this Article: Yusof, N. B. M., Effendi, Y. R. A. B. Y. R., \& Ramli, S. H. Bin. (2019). Expert User Education: Redefining Role of Design and Designers of IR 4.0 in Rehabilitation Setting. International Journal of Academic Research in Business and Social Sciences, 9(13), 348-357.

Copyright: (c) 2019 The Author(s)

Published by Human Resource Management Academic Research Society (www.hrmars.com)

This article is published under the Creative Commons Attribution (CC BY 4.0) license. Anyone may reproduce, distribute, translate and create derivative works of this article (for both commercial and non-commercial purposes), subject to full attribution to the original publication and authors. The full terms of this license may be seen

at: http://creativecommons.org/licences/by/4.0/legalcode

Special Issue: Revolutionizing Education: Challenges, Innovation, Collaboration, 2019, Pg. 348 - 357

http://hrmars.com/index.php/pages/detail/IJARBSS

JOURNAL HOMEPAGE

Full Terms \& Conditions of access and use can be found at http://hrmars.com/index.php/pages/detail/publication-ethics 


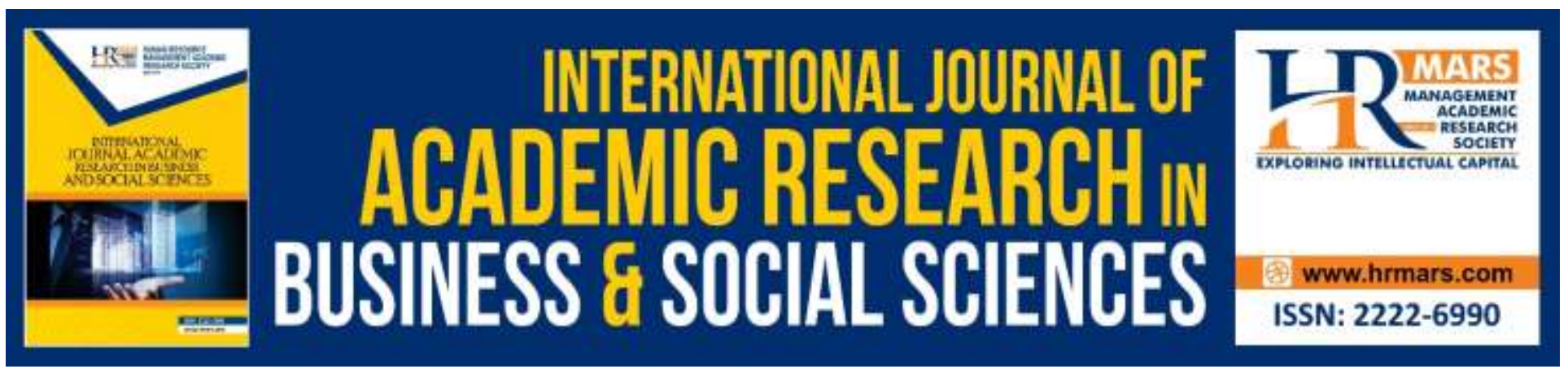

\title{
Expert User Education: Redefining Role of Design and Designers of IR 4.0 in Rehabilitation Setting
}

\author{
Nurhikma Binti Mat Yusof ${ }^{1,2^{*}}$, YM Dr Raja Azmeer Bin YM Raja \\ Effendi2a, Dr Saiful Hasley Bin Ramlib \\ ${ }^{1}$ Dept. of Industrial Design, Faculty of Art \& Design, Universiti Teknologi MARA Cawangan Melaka, \\ Km26, Jalan Lendu, 78000 Alor Gajah, Melaka, Malaysia, ${ }^{2}$ Dept. of Industrial Design,Faculty of \\ Design and Architecture, Universiti Putra Malaysia, Jalan UPM, 43400 Serdang, Selangor, Malaysia \\ Email: hikmayusof@melaka.uitm.edu.my, azmeer@upm.edu.my, shr@upm.edu.my
}

\begin{abstract}
Interdisciplinary is a huge innovation in education. It sets a wide perspective of knowledge boundaries with different background of expertise in order to achieve better outcome and social impact. Innovation in the other way closely related to creative mind as being portray as design thinking. A cross-field research has being conducted between occupational therapist (expert-user) and designer due to innovation activities occurs in the rehabilitation setting. Increasing creation on assistive technology (AT) for patients grows in numbers but unfortunately issues of low rate of usage being highlighted. What went wrong to those creation? The purpose of this paper is to investigate the effective design practice that suits need of interdisciplinary for design intervention in rehabilitation setting. In design education, several approach being applied by the designers to help the non-designer to innovate products in their field such as co-creation. Hence, a total of selected studies from design and innovation journal between year 2010 until 2018 being reviewed using Mendeley to analyse the difference design activities involved. Upon findings, attributes for interdisciplinary for design education for expert-user are including types of user, experience and technology factors. Recommendation for further research in design method for interdisciplinary collaboration for expert-user is perceived to bring better creation by future Design Innovation Catalyst (DIC) where they can adopt design intervention in their field for effective problem solving; either in design or non-design activities. The important of these findings for design interdisciplinary are discussed.
\end{abstract}

Keywords: Co-design Practice, Expert-user, Innovation, Interdisciplinary

\section{Introduction}

This research is a cross discipline research involving design practice and rehabilitation, and it was part of an on-going doctoral research. It is based on one of the variables that is identified as 
education factors in assistive technology (AT) creation which involves expert-user (the occupational therapist) in rehabilitation setting. The goal of AT is to bridge an individual's functional limitations with the demands of the physical environment by reducing the impact of impairments (Gitlin, Levine, \& Geiger, 1993). Unfortunately, issues of low rate of AT usage is highlighted (Gitlin, Levine, \& Geiger, 1993), (Wielandt \& Strong, 2000) and (Copley \& Ziviani, 2004).

This comparative paper will discuss the use of knowledge transfer via design intervention that will be as the commodity in realizing better innovation in the future. Earlier, the research has been started with an online preliminary survey to evaluate innovative activities that seems to happened among the expert-user during therapy session. From the survey, 90 percent of the therapist innovate new tools during rehabilitation session due to certain unsuitability features and functions on the existing products. Followed by this survey is the first paper which to identify attributes of creation in AT. Summary highlighted several themes from the review that are AT prescribe factors, AT equipment factors and AT education factors (Yusof, 2018). The objective of this paper is to investigate the effective design practice that suits need of interdisciplinary for design intervention in rehabilitation setting.

As for the introduction, Department of Occupational Therapist in rehabilitation identified to be the most active department which come out with creation of assistive technology for patients either for assessment or patient's recovery process. The therapists needs to modify or use whatever they have to suit the need of treatment or exercise to the patients towards the recovery process. Although there have a model of theory for problem solving like 'Human Activity Assistive Technology'(HAAT) model (Cook et al.,2008), designing things still a jargon task for them to make in into functions. They are rehabilitation experts but not product design experts. This contributes ineffective innovation made by them for the patients. From the early online survey made to the occupational therapist in Malaysia, challenging part in innovating the assistive technology by preferences are: functionality, idea generation, aesthetic and model making. As the result, 93 percent of the participants ticked 'YES' for need of collaboration with the designer in the future. On the other side of design and product designers, they see this as an opportunity to redefine both roles in other field.

Design practice consists various approach throughout the years with lots of theories and design model immerse from century to century. Previously, design activities only happened among the designers. The innitiatives of collaboration design (co-design) is increasingly popular in many businesses and organizations (Binder, Brandt, \& Gregory, 2008) while Sanders and Stappers (2008) used the term co-creation to refer to "any act of collective creativity, i.e. creativity that is shared by two or more people". The term co-design in a more narrow sense to refer to the "collective creativity as it is applied across the whole span of a design process". Steen et al., 2011 puts the terms "codesign' in focus as creative cooperation during design processes. Diverse experts in their field and experiences came together under this co-design including researchers, designers or developers, and (potential) customers and users. Design thinking knowledge and skills have been transferred from expert designers (authors) to non-designers through toolkit and participatory experiences (Milano et al., 2017). Product performance being improved by taking user factors into consideration during the engineering design phase (Sun, Houssin, Renaud, \& Gardoni, 2016). 


\section{Design for Disability}

In 1970's, design for disability first being introduced under Universal Design (UD). Ronald L. Mace who was an architect, product designer and educator was interpreted the term of UD and founded The Center for Universal Design in 1989. The concept of UD is intended to extinguish the discrimination of people with disabilities from people without any disability (Helvacioglu \& Nazende, 2012) and people to experience the benefit of not only environments but also products that surround us regardless of our ages, sizes of abilities (Helvacioglu \& Nazende, 2012). Design for Disability has been flourishing as designers and visual communicators attempt to address questions of awareness and accessibility and educational model that supports this, working to push the boundaries of our own frames of references both within and beyond the field of design (Gieben-gamal \& Matos, 2017).

\section{New Roles of Design and Designers in Industrial Revolution 4.0 (Ir 4.0)}

Upon Industrial Revolution 4.0 (IR 4.0), it represents a shift of paradigm with a new wave of innovations characterized by the digitization of business, society and our lives and being said that highly connected with innovation (Morrar, Arman, Mousa, Schwab, \& Arman, 2018). The pace of change and the disruptive nature of innovations will require that organizations become more and more agile, intuitive, imaginative, and open to change. This can be achieved only by developing the human-based dimensions of an organization. Therefore, the Fourth Industrial Revolution it is not only about embracing new disruptive digital-based technologies and learning machines, but it is also about shaping organizational environments that let people express their real potentials and be in touch with their positive emotions.(Schiuma, 2017).

In order to enable people to discover and express their creative potentials and being engaged organizations can shape their organizational context into a creative environment. The use of the arts as a learning platform is fundamentally aimed at developing human capital. This transformation is mainly based on the learning processes taking place both at the individual and at group level that nurture the development of employees.

\section{Design Intervention and Design Innovation Catalyst (Dic)}

Because of the user's is very active and innovative, the designer has started to take an initiative to guide the user's to become 'design innovation catalyst' (DIC) (Hammel \& Mosely, 2017). Design itself is a complicated and long process. There is no short cut for good and effective design. Nowadays, there is a lot of application software that makes the design work much easier for the nondesigners especially in graphic design, interior decoration and etc but the impact of the design itself do not reflect the quality and aesthetic meaning to the audience. Hence, design intervention will be a remarkable way to sustain the feasibility of design among the non-designer. Colquhoun et al., 2017 identify four tasks that need to be completed when designing individual-level interventions: identifying barriers, selecting intervention components, using theory, and engaging end-users.

\section{Types of User}

In general, there are several types of user lies in product usage and all have different definitions in design roles. Here are the differences: 
User by Cambridge Dictionary means someone who uses a product, machine, or service. User also indicate normal user that buy certain products and use it.

Lead user are defined as being at the leading edge of markets, and as having a high incentive to innovate (Morrison, Roberts, \& Midgley, 2004).

Expert-user by Oxford Dictionary means a person who is very knowledgeable about or skilful in a particular area. an expert user possesses general (GK), domain - specific knowledge (DSK) and task experience and expertise (TE) (Popovic, 2000).

Hence, expert-user in rehabilitation is referred to the professionals that works in the rehabilitation setting such as doctor, physiotherapist, physical therapist, occupational therapist and any other health professionals involves in the rehabilitation process.

\section{Method}

Comparative study has been made to several design practice that is believed involved in interdisciplinary design. 20 selected journal from design and innovation journal between year 2010 until 2018 being reviewed using Mendeley to analyses the differences involve in design activities. The systematic review process was collected according to the selected design practices that are believed consists interdisciplinary engagement between designer and non-designer that are; co-creation, participatory, user experience, user-centered and universal design. Articles being classified accordingly to the style of design approach, keyword and outcome. Table 1 shows the summary of first review and Table 2 indicate the classifications of design activities by design practice according to participants, focus and method. 
INTERNATIONAL JOURNAL OF ACADEMIC RESEARCH IN BUSINESS AND SOCIAL SCIENCES

Vol. 9, No. 13, Special Issue: Revolutionizing Education: Challenges, Innovation, Collaboration., 2019, E-ISSN: 2222-6990 @ 2019 HRMARS

\section{Results}

Table 1. Sample of summary of design practice

\begin{tabular}{|c|c|c|c|c|}
\hline & Anithar & Aprogantifi & Kcywongli & Outcomen: \\
\hline Co-creation & (Pirinem, 2016) & $\begin{array}{l}\text { collaboration is a } \\
\text { transformative capability that } \\
\text { necessitates the crossiag of the } \\
\text { structural. cultural and other } \\
\text { bonndaries of individuais, } \\
\text { orgunisationa and networkm }\end{array}$ & $\begin{array}{l}\text { Co-design, collaboration, } \\
\text { bousdaries, network }\end{array}$ & $\begin{array}{l}\text { Basriess : organisational } \\
\text { hixrarchy } \\
\text { Enablers ; share user focus, } \\
\text { openness, experimestal } \\
\text { method }\end{array}$ \\
\hline Participatocy & (Milano et al. 2017) & $\begin{array}{l}\text { Design thinking knowiedge } \\
\text { and skills lave been } \\
\text { transferred from expert } \\
\text { desigoers (autbars) to bon- } \\
\text { designers (statts in Universiss) } \\
\text { through toolkit abd } \\
\text { participatory experiences }\end{array}$ & $\begin{array}{l}\text { design strategy, organisational } \\
\text { change, social cooperative, } \\
\text { evaluation }\end{array}$ & $\begin{array}{l}\text { In the future, these activities } \\
\text { sboukt also be transfomed } \\
\text { from expent designers to bon- } \\
\text { designers, who will learn to } \\
\text { use design thinking step-by- } \\
\text { step and make themselves } \\
\text { capoble of conducting this } \\
\text { approuch more independently }\end{array}$ \\
\hline User Centered Design & $\begin{array}{l}\text { (van der Bijl-Brouwer \& van } \\
\text { der Voort, 2014) }\end{array}$ & $\begin{array}{l}\text { an analysis of user centred } \\
\text { design litemane and an } \\
\text { empirical stody of design for } \\
\text { DDUS in design practice. } \\
\text { (DDUS - Design for Dyuamic } \\
\text { and Diverse Une) }\end{array}$ & $\begin{array}{l}\text { Context of Use, Design } \\
\text { Process, Dynatuic and Diverse } \\
\text { Use Situations, Usability, User } \\
\text { Experience, User-Centred } \\
\text { Desiga }\end{array}$ & 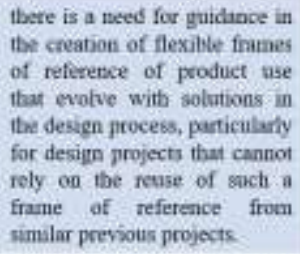 \\
\hline User experience & $\begin{array}{l}\text { (Sun, Houssin, Renaud, A } \\
\text { Gardani, 2016) }\end{array}$ & $\begin{array}{l}\text { imperving the product } \\
\text { performance by taking nser } \\
\text { facton into consideration } \\
\text { daring the engineering design } \\
\text { phase }\end{array}$ & $\begin{array}{l}\text { Innovative design, design } \\
\text { metlbod, user experience, } \\
\text { coniradiction }\end{array}$ & $\begin{array}{l}\text { generate a taser manual by } \\
\text { malyzing the interaction } \\
\text { between product behaviar and } \\
\text { user behaviof during the esrly } \\
\text { design stage }\end{array}$ \\
\hline Universal design & $\begin{array}{l}\text { (Sangelkar, Cowen, \& } \\
\text { Mcadams, 2012) }\end{array}$ & $\begin{array}{l}\text { focts is on understanding the } \\
\text { relatsonship between user } \\
\text { neerts anit product fumction }\end{array}$ & $\begin{array}{l}\text { univensal design, lmman } \\
\text { factors, prothot design. } \\
\text { product modeling, design } \\
\text { activity }\end{array}$ & $\begin{array}{l}\text { using the ICF as a lexicon for } \\
\text { uset actwity and disability, } \\
\text { and applying association rule } \\
\text { mining to unversal prodoct } \\
\text { design }\end{array}$ \\
\hline
\end{tabular}

Table 2. Classification of design activities by design practice 
INTERNATIONAL JOURNAL OF ACADEMIC RESEARCH IN BUSINESS AND SOCIAL SCIENCES

Vol. 9, No. 13, Special Issue: Revolutionizing Education: Challenges, Innovation, Collaboration., 2019, E-ISSN: 2222-6990 @ 2019 HRMARS

\begin{tabular}{|c|c|c|c|c|c|c|}
\hline & & Co-creation & Participatory & Universal besign & User-centered & User experience \\
\hline \multirow[t]{4}{*}{ Participants } & Designer & I & 1 & I & 1 & 1 \\
\hline & Lead user & & I & I & & l \\
\hline & Expert user & I & & & & \\
\hline & Normal user & & & 1 & 1 & 1 \\
\hline \multirow[t]{5}{*}{ Focus } & $\begin{array}{l}\text { Product/ } \\
\text { Service }\end{array}$ & 1 & 1 & 1 & 1 & I \\
\hline & Idea generation & I & 1 & & I & I \\
\hline & Making up & 1 & 1 & & & \\
\hline & Function & I & & 1 & 1 & 1 \\
\hline & Aesthetic & I & & & & \\
\hline \multirow[t]{9}{*}{ Method } & Design brief & / & & & & \\
\hline & Scenario & & I & & & \\
\hline & Mock up & I & 1 & & & \\
\hline & Prototyping & 1 & & & & \\
\hline & Simulation & t & & & & \\
\hline & Case study & 1 & & 1 & 1 & \\
\hline & Software oriented & & & & I & \\
\hline & $\begin{array}{l}\text { Customer } \\
\text { experience }\end{array}$ & & & I & I & 1 \\
\hline & Competition & & 1 & & & 1 \\
\hline
\end{tabular}

Table 1 shows a summary of 20 selected journal for design practices. Shown only one sample over each five categories (co-creation, participatory, user centered design, user experience and universal design) reviewed. According to Table 1, each design practice have own design strategies and approach but involves collaboration with non-designer (user). Collaboration activities detected through keywords such as collaboration, network, social and user (itself). For design approach; design thinking, product performance, toolkit, engineering and product function being emphasized through the design processes.

Under the umbrella of design, user needs and product functions always be the important keys in product design. Identification type of user must be suitable with the type of design practice to be approach. Correct match will end up with effective product outcome as all the desired traits of a product being fulfill in the design. Table 2 is suggested to be guidance for designer to choose before applying the design practice to certain group of users.

\section{Discussion}

\section{Design Practice Vs Rehabilitation Practice}

In relating to user education in rehabilitation setting, main focus is to the occupational therapist (OT) whose spend the most time with patient during rehabilitation process. They are categorized as expert-user in rehabilitation practice and understand most of the treatment and assessment prepared for the patients. According to Silver, Binder, Zubcevik \& Zafonte (2016), physicians and other healthcare professionals are often the end users of medical innovation; however, they are rarely involved in the beginning design stages. This results in ineffective and inefficient solutions with poor adoption rates. Therefore, 
this study may help the innovation process in rehabilitation setting progress efficiently with design practice suggested.

The HAAT Model: Version 3, Cook et al. (2008) by rehabilitation practices emphasizes on 'occupation' and 'occupational performance' as the main attribute and outcome of the AT system rather than focusing the impact of culture on the individual and the assistive technology system. Currently, AT is being created not to train the capability of patient, but rather modifying the context (environment) to suit the patient's ability and limitation. This is likely AT is being prescribed to a patient in fulfilling the assessment and intervention goals. In the other way, AT supposed to encourage independency to certain circumstances that will benefit patient's fast recovery process to fit the occupation in the future. (occupation in the context is referring to patient's daily activity; walking, eating, etc)

In design practice (refer Table 2), a lot of elements in design activities being consider before designing certain products. Details observation on each elements is to make sure engagement between user and product achieved. There is a huge difference of collaboration between user (normal) and lead or expert user. A particular user experiences needs that are not achieved, they will make the adjustments themselves and then fed back to manufacturing companies from these users in the hope that the product will then be produced for them. Meanwhile, focus always on product and currently on service design. Foremost, variations of methods being listed and fiture collaboration made between designer and non-designer may be arranged accordingly suiting the 'activity' (Sangelkar, Cowen, \& Mcadams, 2012) of the expert-user and the design context.

Figure 1. Interpretation of new model of design and rehabilitation practice relationship; originated from HAAT Model Version 3 to AT Creation Model.

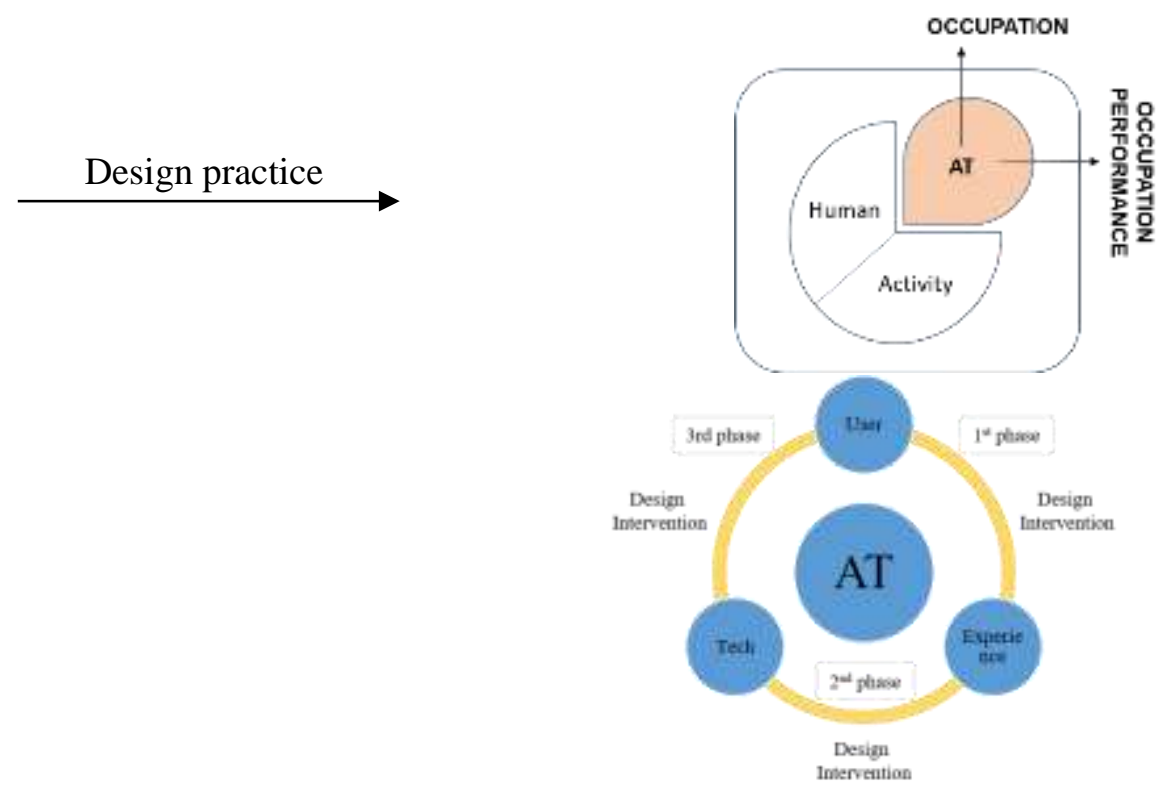

\section{Conclusion}

In this paper, we conclude that there are several criterias that need to be consider before implementing effective design practice (intervention) to the expert-user in rehabilitation setting. Colquhoun et al.,2017 suggested to identify four tasks that need to be completed when designing 
individual-level interventions: identifying barriers, selecting intervention components, using theory, and engaging end-users. Three keywords being emphasized after comparison amongst selected design collaboration practices being made that are user, experience and technology. Referred to the main issue highlighted earlier on the low rate of AT usage, these three keywords seems to have strong connection with elements that appears in HAAT Model Version 3.0 that practised by the expert-user (OT) in rehabilitation. There will be three levels of design intervention phase: (1) The early phase, connecting user and experience (2) The second phase, connecting experience and technology and (3) The final phase, connecting technology with the user. All of these phases involve a well-known transitional process of rehabilitation innovation. The finding shows that the use of linguistic interpretations is significant as a mean of analysis in order to identify design practice preferences. Future study will include exploring relevant theories and suitable technology from barriers and enablers (Pirinen, 2016) in collaboration design to approach the three design intervention phases in engaging the three elements of suggested model of design and rehabilitation practice.

\section{Acknowledgements}

The authors gratefully acknowledge the help of the Ministry of Higher Education of Malaysia in providing the study scholarship. The authors are also thankful to all the co-supervisors in Life and Emotion group (LIMO) of Department of Industrial Design, University Putra Malaysia on the fruitful comments and suggestions throughout the research. Special appreciation of occupational therapists under the Malaysia Occupational Therapy Association for the cooperation on the online survey conducted earlier.

\section{References}

Copley, J., \& Ziviani, J. (2004). Barriers to the use of assistive technology for children with multiple disabilities. Occupational Therapy International, 11(4), 229-243. https://doi.org/10.1002/oti.213

Gieben-gamal, E., \& Matos, S. (2017). Design and Disability. Developing New Opportunities for the Design Curriculum Design and Disability . Developing New Opportunities for the Design Curriculum. The Design Journal, 6925, S2022-S2032.

https://doi.org/10.1080/14606925.2017.1352721

Gitlin, L. N., Levine, R., \& Geiger, C. (1993). Adaptive device use by older adults with mixed disabilities. Archives of Physical Medicine and Rehabilitation, 74(2), 149-152.

https://doi.org/0003-9993(93)90354-D [pii]

Hammel, R., \& Mosely, G. (2017). Educating Design Innovation Catalysts Through Design Interventions. Design Management Academy Conference 2017, (June). https://doi.org/10.21606/dma.2017.83

Helvacioglu, E., \& Nazende, N. (2012). Awareness of the Concept of Universal Design in Design Education. Procedia - Social and Behavioral Sciences, 51, 99-103. https://doi.org/10.1016/j.sbspro.2012.08.125

Milano, P., Pei, X., Zurlo, F., Vignati, A., Fois, L., \& Melazzini, M. (2017). Making Visible : Valuating the Impacts of Design Intervention for Social Cooperative Making Visible : Valuating the Impacts of Design Intervention for Social Cooperative. The Design Journal, (July), S3326-S3339. https://doi.org/10.1080/14606925.2017.1352836 
Morrar, R., Arman, H., Mousa, S., Schwab, K., \& Arman, H. (2018). The Fourth Industrial Revolution ( Industry 4.0 ): A Social Innovation Perspective Author information Rabeh Morrar Saeed Mousa, 1-9.

Morrison, P. D., Roberts, J. H., \& Midgley, D. F. (2004). The nature of lead users and measurement of leading edge status. Research Policy, 33(2), 351-362. https://doi.org/10.1016/j.respol.2003.09.007

Pirinen, A. (2016). The Barriers and Enablers of Co-design for Services, 10(3), 27-42.

Popovic, V. (2000). Expert and Novice User Differences and Implications for Product Design and Useability. Proceedings of the Human Factors and Ergonomics Society Annual Meeting, 44(38), 933-936. https://doi.org/10.1177/154193120004403869

Sangelkar, S., Cowen, N., \& Mcadams, D. (2012). User activity - product function association based design rules for universal products. Design Studies, 33(1), 85-110. https://doi.org/10.1016/j.destud.2011.06.002

Schiuma, G. (2017). Arts catalyst of creative organisations for the fourth industrial revolution, 1-12. https://doi.org/10.1186/s40852-017-0072-1

Sun, X., Houssin, R., Renaud, J., \& Gardoni, M. (2016). Integrating User Information into Design Process to Solve Contradictions in Product Usage. Procedia CIRP, 39, 166-172. https://doi.org/10.1016/j.procir.2016.01.183

Wielandt, T., \& Strong, J. (2000). Compliance with prescribed adaptive equipment: A literature review. British Journal of Occupational Therapy, 63(2), 65-75. https://doi.org/10.1177/030802260006300204 